\title{
HEVES MEGYE TERÜLETFEJLESZTÉSÉNEK FŐBB ASPEKTUSAI
}

\author{
Szabó Róbert
}

\section{Összefoglalás}

Heves megyére a magyar megyék között az elmúlt évtizedekben mindig az átlagosság volt a jellemzö. Átlagos területü, átlagos népességü, átlagosan iparosodott, átlagos életszinvonalú stb. Az elmúlt évek fejlödési tendenciáinak és eredményeinek ismeretében úgy érzem, vehetem a bátorságot, hogy megfogalmazzam azt az állitást, hogy manapság Heves megye egyike az ország legdinamikusabban fejlödö megyéinek. Ez a tanulmány a koronavirus-járvány idején iródott, ennek a világméretü járványnak a gazdasági hatásait még nem vehette figyelembe. Heves megyének a járványt megelözö gazdasági állapotáról, az itt folyó területfejlesztési munkáról, valamint a megye lehetöségeiröl és kihivásairól ad egy pillanatképet.

Kulcsszavak: területfejlesztés, Heves megye, TOP

JEL: J10

\section{THE MAIN ASPECTS OF THE REGIONAL DEVELOPMENT OF HEVES COUNTY}

\begin{abstract}
Heves county is a geographically diverse area; its northern part is mountainous (the Matra and Bükk are the two highest mountain ranges in Hungary), while at south it includes a part of the Great Hungarian Plain. From south it is bordered by Lake Tisza, the largest artificial lake in Hungary. The site of Heves county may advance a positive image of a potential 'bridge role' in the planning and acting of both medium and longterm regional development. The county is well provided with nature capital, and it is in possession of close linking points towards Hortobágy and Lake Tisza, which areas already hold good cooperation possibilities of complex rural development and tourism.
\end{abstract}

Keywords: regional development, Heves county, TOP

DOI: $10.33032 /$ acr.2020.10.1.111 


\section{Bevezetés}

\section{Heves megye rövid bemutatása föbb gazdasági mutatói tükrében}

Heves megyére a magyar megyék között az elmúlt évtizedekben mindig az átlagosság volt a jellemző. Átlagos területű, átlagos népességü, átlagosan iparosodott, átlagos életszínvonalú stb. Bármilyen statisztikát vizsgáltunk (munkaerőpiaci, demográfiai, gazdasági) általában átlagos vagy kicsivel átlag alatti eredmények jellemezték a megyét. Eddig. Természetesen a megyének nincsenek területbővítési törekvései, a népesség is maradt átlagos, viszont a gazdasági teljesítmény, életszínvonal, munkanélküliség területén komoly fejlődésnek indult a térség. Ha az ez évi vagy tavalyi KSH-jelentéseket böngésszük, megfigyelhető, hogy Heves megye több gazdasági mutatóban is az ország megyéinek élbolyába zárkózott fel. Az elmúlt évek fejlődési tendenciáinak és eredményeinek ismeretében úgy érzem, vehetem a bátorságot, hogy megfogalmazzam azt az állítást, hogy manapság Heves megye egyike az ország legdinamikusabban fejlődő megyéinek.

A fenti megállapítást alátámasztandóan íme néhány beszédes, társadalmi-gazdasági jellegű $\mathrm{KSH}$-adat.

Az egy lakosra jutó ipari termelés tekintetében, ami talán a legfontosabb gazdasági aktivitást mérő mutató, Heves megye a megyék és Budapest közti rangsorban az ötödik. A kelet-magyarországi megyék közt az első. Az országos átlag 2019. I-IV. negyedévben 3532 ezer Ft, míg ez az érték Heves megyében 5259 ezer Ft volt. Ez közel másfélszerese az országos átlagnak.

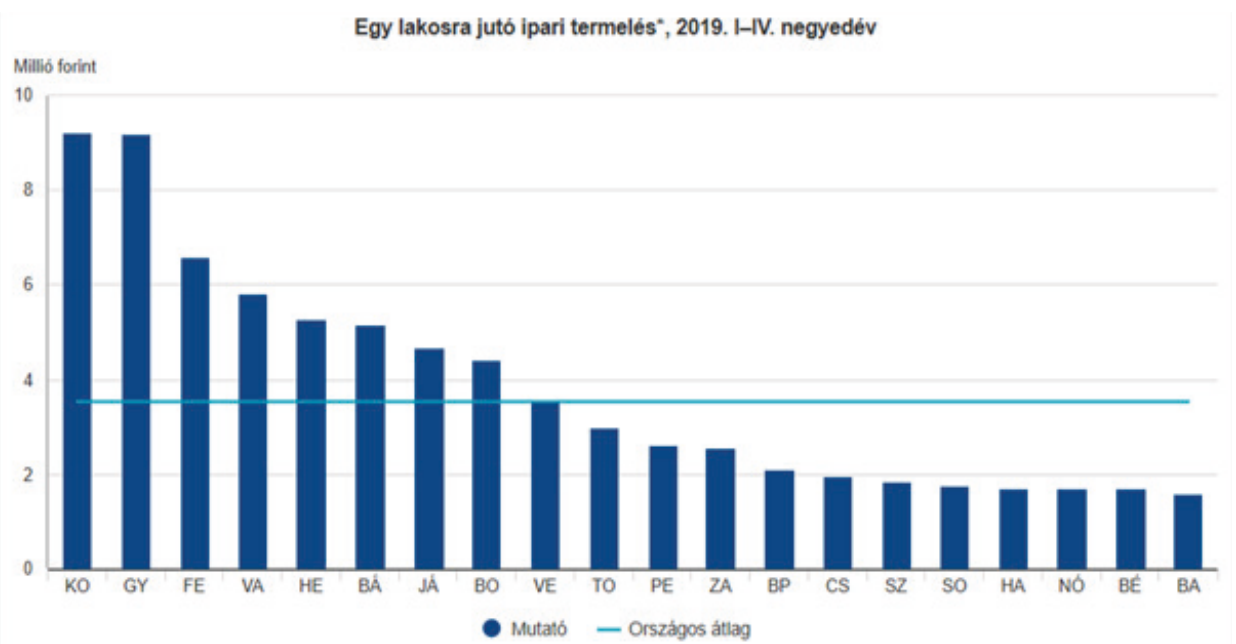

1. ábra: Egy lakosra jutó ipari termelés Heves megyében 2019-ben Forrás: $K S H$ 
Ez a növekvő gazdasági teljesítmény, amennyiben meg tudjuk tartani a lendületet, jó alapul szolgálhat a megye területfejlesztéséhez, amelynek legfőbb célja a megye élhetőségének és az itt élö emberek életszínvonalának minőségi javítása.

A havi nettó átlagkereslet tekintetében Heves megye a hatodik a megyék és Budapest rangsorában, és itt is csak nyugat-magyarországi megyék előzik meg. Kelet-Magyarországon Heves megyében lehet átlagosan a legmagasabb bért keresni, 2019-ben 225027 Forintot. Bár azt is hozzá kell tenni, hogy az országos átlagot - ami 244609 Ft - még nem éri el Budapest kimagasló, gazdaságicentrum-jellegéből adódó, magas átlagkeresetei miatt. Valószínű még jó ideig nem is fogja.

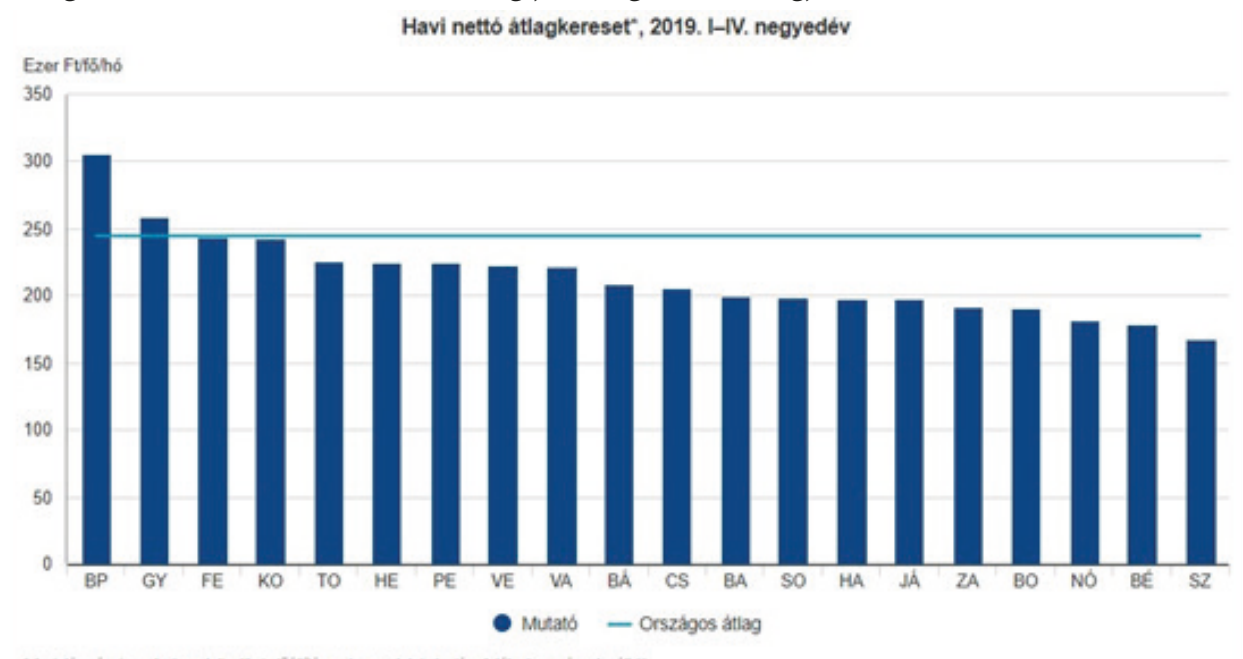

2. ábra: Havi nettó átlagkerest Heves megyében 2019-ben Forrás: KSH

Az előző két ábra egy pillanatképet mutatott a gazdasági aktivitás és a keresetek terén. Mindkét mutató vizsgálata kikerülhetetlen, ha egy megye vagy térség gazdasági, társadalmi állapotát szeretnénk felmérni. De fontosabb következtetéseket csak úgy lehet levonni, ha hosszabb időintervallumot vizsgálunk. Ezért is fontosnak tartom, hogy ne csak a jelenlegi adatokat tekintsük meg, hanem az elmúlt évek trendjeit is bemutassam.

Ha az egy lakosra jutó ipari termelést 2010-től egészen napjainkig vizsgáljuk, jól kirajzolódik egy egyértelmű növekedési trend, ami jóval intenzívebb növekedést mutat, mint az országos átlag. Némiképp árnyalja a pozitív képet, hogy mivel az ipari termelést a KSH före bontja, a növekedés intenzitását az is befolyásolja, hogy a megye évről évre komoly demográfiai deficitet szenved el, ami az országos átlagot meghaladja. Átlagosan mintegy 3000 fővel csökken Heves megye lakossága évente. Nem érezném tisztességesnek ezt a tényt elhallgatni, és fontos is hangsúlyozni, hogy ezen a területen a megyének még sok a tennivalója. 
Míg 2010-ben az egy lakosra jutó ipari termelés 2033 ezer Ft volt, ami kevéssel az országos érték (2044 ezer Ft) alatt volt, addig 2019-re már megközelítette az országos átlag 150\%-át. Ez egy intenzív iparosodási folyamatnak köszönhető, ami 2010-esévek elején indult és napjainkban is tart. Évről évre új gyárak épülnek (Apollo Tyres, Viresol, RUAG Aerostructures), valamint sok meglévő vállalat hajt végre kapacitásnövelő beruházásokat (Bosch, ZF, Procter\&Gamble, SBS, Mátrametál stb.) Jelenleg is több cég tervez bővítést, valamint jelentős iparipark-beruházások vannak folyamatban a megyében. Ebből arra lehet következtetni, hogy ez a pozitív trend a jövőben fennmarad.

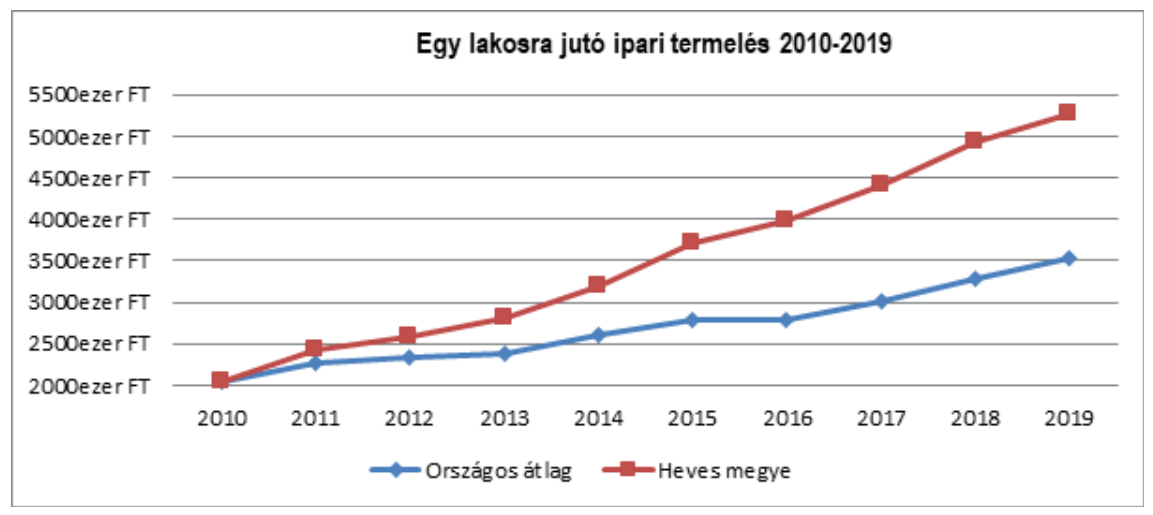

\section{3. ábra: Egy lakosra jutó ipari termelés Heves megyében 2019-ig}

Forrás: $K S H$

Ha a havi nettó átlagkereset elmúlt tíz éves trendjét vizsgáljuk, akkor megállapítható, hogy a megyei keresők bérszínvonala követi az országos átlagot, de folyamatosan alatta van egy kevéssel.

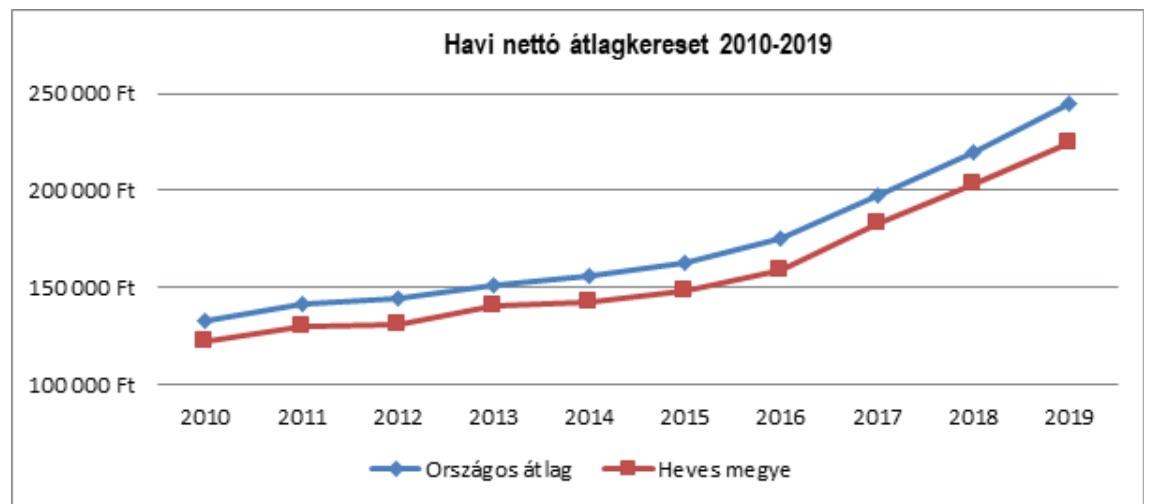

4. ábra: Egy lakosra jutó havi nettó átlagkereset Heves megyében 2019-ig Forrás: $K S H$ 
Ahogyan a megye gazdasági teljesítménye növekedett az elmúlt években, úgy csökkent a munkanélküliség. Jó érzés kimondani, hogy jóformán megszűnt a munkanélküliség a megyében. Ami még van, az jórészt strukturális jellegű munkanélküliség, amit képzési és átképzési programokkal a Megyei Önkormányzat a Kormányhivatal Munkaügyi Központjával közösen, európai uniós források felhasználásával próbál csökkenteni.

A Heves Megyei Kereskedelmi és Iparkamara felmérései szerint a megyének körülbelül 2000 fö többletmunkaerőre lenne szüksége.

2019. IV. negyedévében Heves megyében a munkanélküliségi ráta a KSH adatai szerint 2,8\% volt, ami $0,5 \%$-kal alacsonyabb, mint az országos átlag, a megyék és Budapest rangsorában a kilencedik helyet elfoglalva.

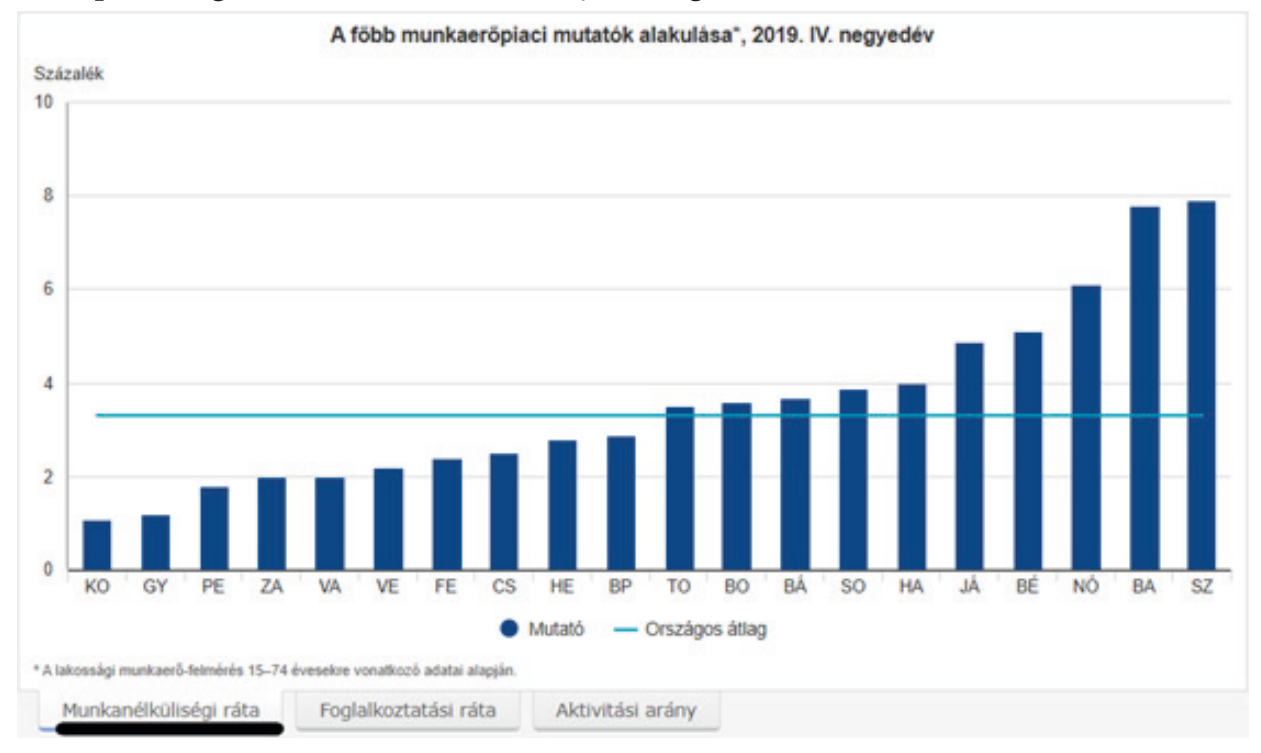

5. ábra: Főbb munkaerőpiaci mutatók alakulása Heves megyében

Forrás: KSH

Azért ez nem volt mindig így. Ha egy öt évvel ezelőtti statisztikát nézünk (2014. IV. negyedév), akkor láthatjuk, hogy Heves megye a nem túl előkelő 14. helyet foglalta el a megyék és Budapest rangsorában. 8,4\%-os munkanélküliség volt, ami 1,3\%-kal magasabb volt, mint az országos átlag.

Összegezve elmondható, hogy az országhoz hasonlóan Heves megye gazdasága is az elmúlt években növekvő pályára állt. A növekedés üteme nagyobb, mint az országos. Ezt támasztják alá a megye gazdasági mutatói is. Fontos jövőbeli kihívás a növekedés dinamikájának a fenntartása, valamint a gazdasági eredmények megőrzése mellett a települések élhetőségének és az itt élő emberek életminőségének javítása. 


\section{Eredmények}

\section{A megyei önkormányzatok mint a terïletfejlesztés motorjai}

A magyar közigazgatás 2010-es évek első felében lezajlott reformja következtében a helyi és térségi fejlesztéspolitikában új keretek jöttek létre. A legfontosabb változás, melynek legföbb célja a területi egyenlőtlenségek csökkentése, hogy a megyei önkormányzatok erős tervezési és területfejlesztési feladatköröket kaptak.

A 2007-2013-as programozási időszak regionális operatív programjainak (ROP) tapasztalatai alapján jól látszott, hogy a decentralizált források, ha azok átgondolt, jól előkészített elképzelések mentén valósulnak meg, akkor nagymértékben hozzájárulnak az adott térség vagy megye fejlődéséhez. A ROP-ok a 2007-2013-as fejlesztési ciklus egyik legjobban teljesítő operatív programjai voltak, ez igazolta a decentralizált forrásallokáció létjogosultságát. A még nagyobb hatékonyság érdekében fontos jól meghatározni, hogy mi az ideális területi szint, ahol a rendelkezésre álló decentralizált források hasznosulnak. A térségi szereplők visszajelzései, valamint szakmai megfontolások alapján a 2014-2020-as programozási időszak decentralizált forrásallokációjának területi szintje a megye lett.

Személyes véleményem szerint ez egy kulcsfontosságú döntés volt a tervezés szempontjából. Mint a Heves Megyei Önkormányzat elnöke volt szerencsém részt venni mind a regionális, mind a megyei szinten működő operatív programok megvalósításában. Véleményem szerint a régió mint területfejlesztési egység, tervezés szempontjából nehezen értelmezhető Magyarországon (Bujdosó Z.-Remenyik B., 2008, Bujdosó et al., 2011). Nem történelmi alapokon nyugszik, kialakítása külső megfelelés által vezérelve, mesterségesen történt. Területén belül térségi kohézió nincs. Ezáltal komplex fejlesztési koncepció kialakítása nem könnyü feladat. Osztom az országos döntéshozók álláspontját, miszerint az ideális fejlesztéspolitikai területi egység Magyarországon a megye. 1000 éves történelmi alapokon nyugszik, elég nagy, hogy komplex, egymásra épülő, szinergiákon alapuló fejlesztésekben gondolkodjunk, de a régiókkal ellentétben még átlátható, és területi kohézión alapul.

A megyei önkormányzatok a 2014-2020-as programozási időszak sikeres megvalósítása érdekében az alábbi tervezési folyamatot követték:

1. Megyei szintű helyzetfeltáró dokumentumok elkészítése

2. Megyei területfejlesztési koncepció elfogadása

3. Megyei szintű fejlesztési igényfelmérés, projektgyüjtés

4. Megyei területfejlesztési program elfogadása

5. Megyei integrált területi program megalkotása

6. Partnerség biztosítása

7. Területi koordináció folyamatos ellátása 


\section{Heves megye területfejlesztési célrendszere}

2014. februárban a Heves Megyei Önkormányzat elfogadta a megye területfejlesztési koncepcióját, ami egy hosszú helyzetfeltáró és stratégiaalkotó munka eredménye volt. Ebben sikerült esszenciálisan megfogalmazni a megye jövőképét:

„Heves megye magyarország harmonikusan fejlődo”, élhető megyéje”

„Heves megye a megfelelően képzett és képezheto”, egészséges humán tőkére támaszkodó, innovációorientált, versenyképes és kiszámíthatóan fejlődő gazdaságával, természeti erőforrásainak fenntartható használatával és társadalmi erőforrásainak, közösségeinek folyamatos fejlesztésével, munkahelyek teremtésével és egyre javuló közbiztonságával 2030-ra a nemzetgazdaság fontos szereplőjévé válik.”

Mikor azon gondolkodtunk, hogy milyen Heves megyét is szeretnénk építeni, abban minden szereplő egyetértett, hogy a fókuszban az élhetőség legyen. Az értelmezésünkben a területfejlesztés legfontosabb célja az élhetőség, az emberi életminőség minél magasabb szintre emelése. Minden más csak a célunk elérését segítő eszköz.

A fent megfogalmazott irányelvek mentén elkészítettük Heves megye területfejlesztési koncepciójának célrendszerét.

\section{Heves megye területfejlesztési koncepciójának célrendszere:}

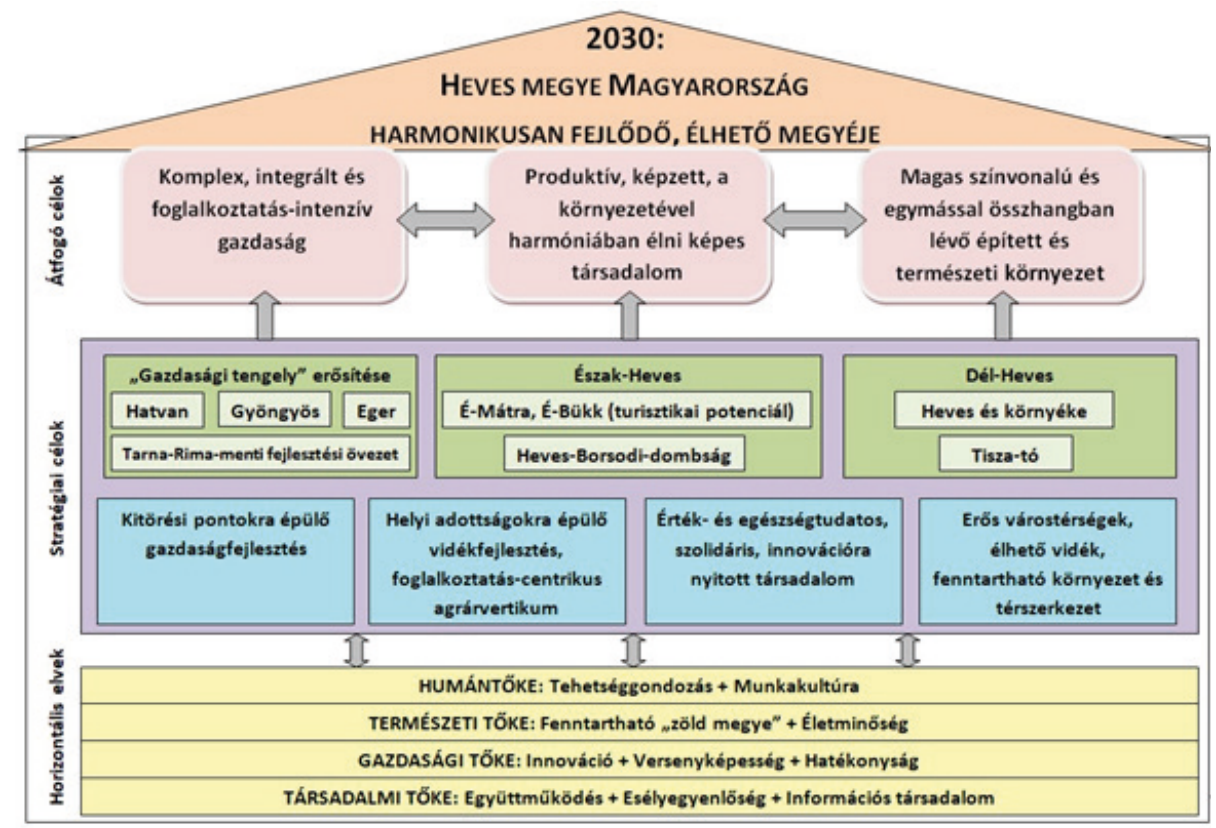

6. ábra: Heves megye területfejlesztésének célrendszere

Forrás: Heves megye területfejlesztési koncepciója 
A területfejlesztési koncepció célrendszerének megalkotásakor területfejlesztési szempontból három területegységre osztottuk Heves megyét, melyek eltérő fejlesztésstratégiai megközelítést igényelnek.

1. „Gazdasági tengely”: a megyeközépső,M3-asautópálya menti területeit valamint Egert foglalja magában. Itt koncentrálódik az ipari termelés 90\%-a, valamint ittél a lakosság többsége, alapvetően városias térség, jelentős innovációs potenciállal. Hiányzó gyorsforgalmi úthálózati kapcsolatok kiépitése, vállalkozói aktivitás növelése, innovációs potenciál fejlesztése. Erösiteni kell a hazai és helyi beszállitói együttmüködéseket. Biztositani kell a meglévö és potenciális telephelyek infrastrukturális fejlesztését, valamint a megfelelö képzett munkaeröt. Az ipari és infrastrukturális fejlesztések mellett kiemelt cél a turisztikai versenyképességük fejlesztésekkel történö megerösitése (Eger, Mátra, termálvizek, bor, gasztronómia). (Dávid et al., 2007)

2. Észak-Heves: a megye északi része hegyvidéki jellegéből adódóan elzártabb, társadalmilag hátrányos helyzetű térség, jelentősebb számú alacsony lakosságszámú településsel, kiemelkedő természeti, turisztikai és táji adottságokkal.

3. Infrastrukturális fejlesztések, amik a települések elérhetőségi feltételeit valamint a mobilitás lehetőségeit egyaránt biztositják. Települési szolgáltatások minöségi és mennyiségi fejlesztése az élhetöség növelése érdekében, ezáltal erösitve a térség népességmegtartó erejét. Potenciális kitörési pont a természeti adottságok vonzerövé fejlesztése, fogadókapacitás elemeinek kiépitése, minöségi szálláshelyfejlesztés (Parád, Bükkszék, Sirok, Szilvásvárad). Helyben müködö KKV-k támogatása. Közmunkaprogram.

4. Dél-Heves: a megye déli része szintén hátrányos helyzetű járásokat foglal magában, jobb elérhetőséggel, de a klímaváltozásnak jobban kitett, illetve egykori iparát vesztett térség, viszont a Tisza-tó mint komplex fejlesztési terület kitörést jelenthet.

5. Legfontosabb közlekedésfejlesztési cél az É-D-i és a Jászság felé a megyehatáron átvezetö utak javitása, kialakitása, ezáltal elösegitve a települések egymás közötti együttmüködését és a gazdasági létesitmények betelepülésének lehetöségét. Az agrárium versenyképességének megörzése, melyhez jó alapot biztosithat a jó minöségü termöföld, illetve a fiatal pályakezdök gyors karrierlehetösége (Herdon-Zörög, 2012; Szücs et al. 2013) A Tisza-tó egységes ökoturisztikai fejlesztése. A hátrányos helyzetű társadalmi rétegek felzárkóztatása, a területi szegregátumok megszüntetése.

Az átfogó céloknál gazdasági, társadalmi és környezeti célokat fogalmaztunk meg:

6. Komplex, integrált és foglalkoztatásintenzív gazdaság. Az alacsony foglalkoztatási ráta emelése, magas hozzáadott értékü munkahelyek létesitése, piacképes tudással rendelkezö munkaerö biztositása, gazdasági infrastruktuira kiépitése, fejlesztése. 
7. Produktív, képzett, a környezetével harmóniában élni képes társadalom. A negativ népesedési folyamatok mérséklése, a családok megerösitése, a gyermekvállalás feltételeinek javitása, a társadalmi egyenlötlenségek csökkentése, a népesség szellemi, erkölcsi, tudásban, készségekben és értékekben való gyarapodásának elösegitése.

8. Magasszínvonalú és egymássalösszhangban lévőépítettés természeti környezet. Heves megye kiemelkedö természeti, kulturális értékeinek és épitett örökségének megóvása a jövö generációi számára. Az energiahatékonyság növelése, hatékony hulladékgazdálkodás. Természettel összhangban élö, klimatudatos nevelés.

\section{Heves megye területfejlesztési eszközrendszere - Településfejlesztési Operativv Program}

A megfogalmazott célrendszerekre alapozva a megyei önkormányzat minden térségi szereplőt bevonva elkészítette a TOP forráskeretéhez igazodó, racionális forrásfelhasználást és a multiplikátorok érvényesülését lehetővé tevő integrált területi programját.

A TOP által biztosított forrásokra két területi szinten lehet tervezni: megyei és megyei jogú városi (MJV) szinten, a program által meghatározott indikatív forráskerettel.

A TOP prioritástengelyei által biztosított források hatékony, a megfogalmazott célokat elősegítő felhasználásával fontos lépést tehetünk a harmonikusan fejlődő, élhető Heves megye kialakításában.

\begin{tabular}{|c|c|}
\hline A TOP prioritásai és intézkedései & $\begin{array}{l}\text { Forrásallokáció } \\
\quad(\text { Mrd Ft) }\end{array}$ \\
\hline $\begin{array}{l}\text { 1. prioritástengely: Térségi gazdasági környezet fejlesztése } \\
\text { a foglalkoztatás elösegítésére }\end{array}$ & 18,263 \\
\hline 1.1. - Helyi gazdasági infrastruktúra fejlesztése & 7,563 \\
\hline $\begin{array}{l}\text { 1.2. - Társadalmi és környezeti szempontból fenntartható } \\
\text { turizmusfejlesztés }\end{array}$ & 4,170 \\
\hline $\begin{array}{l}\text { 1.3. - A gazdaságfejlesztés és a munkaerö-mobilitás } \\
\text { ösztönzését szolgáló közlekedésfejlesztés }\end{array}$ & 3,074 \\
\hline $\begin{array}{l}\text { 1.4. - A foglalkoztatás segítése és az életminőség javítása } \\
\text { családbarát, munkába állást segítő intézmények, } \\
\text { közszolgáltatások fejlesztésével }\end{array}$ & 3,456 \\
\hline $\begin{array}{l}\text { 2. prioritástengely: Vállalkozásbarát, népességmegtartó } \\
\text { településfejlesztés }\end{array}$ & 6,931 \\
\hline $\begin{array}{l}\text { 2.1. - Gazdaságélénkítő és népességmegtartó } \\
\text { településfejlesztés }\end{array}$ & 6,931 \\
\hline
\end{tabular}




\begin{tabular}{|c|c|}
\hline A TOP prioritásai és intézkedései & $\begin{array}{l}\text { Forrásallokáció } \\
(\mathrm{Mrd} \text { Ft })\end{array}$ \\
\hline $\begin{array}{l}\text { 3. prioritástengely: Alacsony szén-dioxid-kibocsátású } \\
\text { gazdaságra való áttérés kiemelten a városi területeken }\end{array}$ & 9,438 \\
\hline 3.1. - Fenntartható települési közlekedésfejlesztés & 4,417 \\
\hline $\begin{array}{l}\text { 3.2. - Önkormányzatok energiahatékonyságának és } \\
\text { a megújuló energiafelhasználás arányának növelése }\end{array}$ & 5,021 \\
\hline $\begin{array}{l}\text { 4. prioritástengely: A helyi közösségi szolgáltatások } \\
\text { fejlesztése és a társadalmi együttmúködés erősítése }\end{array}$ & 2,661 \\
\hline 4.1. - Az egészségügyi alapellátás infrastrukturális fejlesztése & 0,673 \\
\hline $\begin{array}{l}\text { 4.2. - A szociális alapszolgáltatások infrastruktúrájának } \\
\text { bővítése, fejlesztése }\end{array}$ & 0,851 \\
\hline 4.3. - Leromlott városi területek rehabilitációja & 1,137 \\
\hline $\begin{array}{l}\text { 5. prioritástengely: Megyei és helyi emberierőforrás- } \\
\text { fejlesztések, foglalkoztatásösztönzés és társadalmi } \\
\text { együttmúködés és foglalkoztatásösztönzés }\end{array}$ & 4,400 \\
\hline $\begin{array}{l}\text { 5.1. - Foglalkoztatásnövelést célzó megyei és helyi } \\
\text { foglalkoztatási együttmüködések (paktumok) }\end{array}$ & 3,251 \\
\hline $\begin{array}{l}\text { 5.2. - A társadalmi együttműködés erősítését szolgáló helyi } \\
\text { szintű komplex programok }\end{array}$ & 0,423 \\
\hline 5.3. - Helyi közösségi programok megvalósítása & 0,726 \\
\hline
\end{tabular}

1. táblázat: A Területfejlesztési Operatív Program prioritásai és forrásallokációja Heves megyében (MJV nélkül)

Forrás: Heves megye területfejlesztési koncepciója

\section{Összegzés}

2020. április 26-ig Heves megyében 361 támogatói döntést hozott az irányító hatóság a TOP-ban. Ez (Egert is beleszámítva) 55,812 milliárd forint megítélt támogatást jelent. Ekkora forrásból épülnek utak, ipari parkok, kerékpárutak, bölcsődék és még sok minden más a megyében. Hozzájárulva a megye versenyképességének megőrzéséhez és az itt élő emberek életminőségének növekedéséhez.

Természetesen még sok feladat van előttünk, de ha megnézzük, hogy honnan indultunk a 2010-es évek elején, és most hol tart a megye, úgy érzem az elért eredmények 
némi optimizmusra adhatnak okot. Ha Heves megye jól sáfárkodik a lehetőségeivel, akkor a területfejlesztési koncepcióban felvázolt jövőkép, miszerint Heves megye Magyarország harmonikusan fejlődő élhető megyéjévé válik, nem csak egy vízió marad.

\section{Hivatkozott források}

[1.] Bujdosó Z. - Remenyik B. (2008): A hazai turisták életminőségének a feltérképezése az Észak-Magyarország Régióban. In: Dávid L. (szerk.): A turizmus szerepe az Észak-Magyarország Régióban I-II. Gyöngyös, Magyarország: Károly Róbert Főiskola, pp. 40-48., 9 p.

[2.] Bujdosó Zoltán - Dávid Lóránt - Remenyik, Bulcsú - Tóth, Géza (2011): Connection between tourism and regional development on the HungarianCroatian border. Central European Regional Policy And Human Geography 1: 2 pp. 27-40., 14 p.

[3.] Dávid Lóránt - Tóth Géza - Bujdosó Zoltán - Herneczky Andrea (2007): A turizmus és a regionális versenyképesség kapcsolatának mutatói a Mátravidék példáján keresztül. Eszak-Magyarországi Stratégiai Füzetek IV. évf.: 1. szám pp. 3-20., 18 p.

[4.] Herdon Miklós - Zörög Zoltán (2012): The perceptions of agricultural graduates on the correlation of their labour market situation and qualification in Hungary. Journal of Ecoagritourism 8:2 pp. 326-331. 6p.

[5.] Heves Megye Területfejlesztési Koncepciója https://hevesmegye.hu/files/ koncepcio/helyzetertekeles.pdf

[6.] Szücs Csaba - Zörög Zoltán - Csomós Tamás (2013): Career Tracking of Agricultural Graduates in Hungary. Annals of The Polish Association of Agricultural and Agribusiness Economists XV. pp. 409-415., 7 p.

[7.] Területfejlesztési Operatív Program https://www.hevesmegye-tfkft.hu/

\section{Szerző}

Szabó Róbert

Elnökhelyettes

Heves Megyei Közgyűlés, Eger

szaboroberthevesmegye@gmail.com 